\title{
Effect of daidzein on Parkinson disease induced by reserpine in rats
}

\author{
Radha Goel $^{\oplus *, 1}$, Rabia Chaudhary ${ }^{1}$ \\ ${ }^{1}$ I.T.S College of Pharmacy, Ghaziabad, Uttar Pradesh, India
}

\begin{abstract}
Parkinson disease is a neurodegenerative disorder characterised by the cardinal symptoms of stiffness, resting tremor, slowness (bradykinesia) and reduction of movement (hypokinesia). Involvement of oxidative damage has been reported in the pathophysiology of Parkinson disease and its related complications. The purpose of this study was to examine the effect of daidzein to quench the free radicals produced as a result of the increased oxidative stress in Parkinson disease.Parkinson disease is induced by administration of reserpine ( $5 \mathrm{mg} / \mathrm{kg} /$ day, i.p) for 5 consecutive days. The symptoms of PD such as tremors, akinesia and rigidity were evaluated. The effect was evaluated by assessing various behavioral parameters (grip strength and locomotor activity), biochemical parameters (lipid peroxidation, and reduced glutathione), as well as histopathological parameters in brain tissue. Daidzein (an antioxidant) was administered at the dose of 50 and $100 \mathrm{mg} / \mathrm{kg}$, p.o. once daily for 5 days. Reserpine significantly causes tremor, rigidity, akinesia and oxidative damage which were reversed by daily administration of daidzein when compared toreserpine group. There was a significant histological improvement in the neuronal degeneration in brain tissue with daidzein. So, the results indicated the protective effect of daidzein against $\mathrm{PD}$.
\end{abstract}

Keywords: Daidzein. Reserpine. Carbidopa and Levodopa combination. Parkinson.

\section{INTRODUCTION}

Parkinson Disease is a disorder of the central nervous system, involving primarily a degeneration of certain nerve cells in the substantia nigra. PD is a slowly progressive neurodegenerative disease characterized by Pill rolling tremors, Akanthisia (inability to sit still), rigidity, resting tremor, kinesis (akinesia,dyskinesia), "freezing" and loss of postural reflexes, Instable (stooped) posture (Lorraine, Anthony, 2015). It is estimated that more than 1 percent of the population over age 65 are afflicted with Parkinson's disease which can be increased with age (Pavan, Venkatraman, 2012). Oxidative stress is thought to be the common underlying mechanism that leads to cellular dysfunction and demise. In Parkinson disease, oxidative stress induced by free radicals damages neuronal membrane lipids, proteins and other components of brain tissues and may cause dopaminergic degeneration in the substantia nigra

\footnotetext{
*Correspondence: R.Goel. I.T.S College of Pharmacy, Delhi-Meerut Road, Ghaziabad, Uttar Pradesh-201206, India. Phone: 9711736818. E-mail: radhamit2006@gmail.com,

R. Chaudhary. Department of Pharmacology, I.T.S College of Pharmacy, Delhi - Meerut Road, Ghaziabad, Uttar Pradesh, India
}

(Jenner et al.; 1992). Antioxidant helps cells to cope with oxidative stress by effectively quenching free radicals. Antioxidants are generally regarded as safe - vitamin E, beta-carotene and lipoic acid (Gołembiowska et al.; 2007). Daidzein is an isoflavone aglycone and an antioxidant that capable of stabilizing or deactivating free radicals before they attack cells (Xiaoping et al.; 2012). The study showed that daidzein is helpful in preventing breast cancer (Xiaoping et al.; 2012), osteoporosis (Ricciotti, Khaodhiar, Blackburn, 2005), and relief in menopause (Fonseca, Wendy, 2004).So, the objective of this study is to investigate the effects of daidzein in Parkinson disease induced by reserpine in rats.

\section{MATERIAL AND METHOD}

\section{Animals}

All experiments were performed on adult wistar rats weighing 150-250 g. The animals were procured from the Animal House, I.T.S College of Pharmacy Muradnagar, Ghaziabad. Animals were housed in group of 6 per cages, maintained at $23 \pm 2{ }^{\circ} \mathrm{C} ; 55 \pm 5 \%$ humidity in a natural lightand dark cycle, with free access to food 
and water. The experiments were performed during the light cycle in awake, freely moving animals that were adjusted to laboratory conditions before proceeding with the experiments. All animal procedures were approved by the ethical committee at our institution (CPCSEA registration number: 1044/PO/Re/S/07/CPCSEA) and performed in compliance with institutional guidelines for the care handling of experimental animals.

\section{Experimental protocol}

The animals were divided into eight groups of six rats. Daidzein was administered at a dose of 50 and $100 \mathrm{mg} / \mathrm{kg}$ (Bayer, Colnot, Dekant, 2001). L-dopa + carbidopa was administered at a dose of $30 \mathrm{mg} / \mathrm{kg}$ (Colpaert, 1987). Reserpine was given to all groups at the dose of $5 \mathrm{mg} / \mathrm{kg}$ i.p once in a day for 5 days consecutively. The drug treatment was given for 5 days and observations were made after 24 hours of the last treatment of reserpine. All the groups have undergone behavioral, biochemical and histopathological tests. The drugs were administered orally except group 2 and 3 which were given i.p and s.c route respectively (Vandanaet al.; 2015). An equivalent volume of CMC (Carboxy Methyl Cellulose) in saline was given to control groups. All the drugs were given in volumes of $10 \mathrm{~mL} / \mathrm{kg}$.

TABLE I - Experimental design

\begin{tabular}{lcc}
\hline Group & Treatment & Dose $\mathrm{mg} / \mathrm{kg}$ \\
\hline 1 & Control (CMC in Saline) & $10 \mathrm{~mL} / \mathrm{kg}$ \\
2 & Reserpine & $5 \mathrm{mg} / \mathrm{kg}$ \\
3 & Control (DMSO) & $10 \mathrm{~mL} / \mathrm{kg}$ \\
4 & L-dopa + Carbidopa & $100 \mathrm{mg} / \mathrm{kg}$ \\
5 & Daidzein & $50 \mathrm{mg} / \mathrm{kg}$ \\
6 & Daidzein & $100 \mathrm{mg} / \mathrm{kg}$ \\
7 & L-dopa + Carbidopa + Daidzein & $50+100 \mathrm{mg} / \mathrm{kg}$ \\
8 & L-dopa + Carbidopa + Daidzein & $100+100 \mathrm{mg} / \mathrm{kg}$ \\
\hline
\end{tabular}

\section{Parameter to be assessed}

\section{Induction of Parkinson disease by resepine}

Reserpine, the antihypertensive agent induces depletion of central catecholamines stores. Injection of reserpine in rats causes hypokinesia, rigidity, and tremors. The animals were treated with reserpine $(5 \mathrm{mg} / \mathrm{kg}$, i.p., for 5 consecutive days). After $24 \mathrm{~h}$ of last treatment animals was tested for induction of severity of tremors by giving the scores as follows: No tremors-0, occasional twitches-1, moderate or intermittent twitches-2, continues tremors-3. The number of tremors was counted for $5 \mathrm{~min}$. If animals were not showing tremors then 0 score was be given, if animals showed 1 or 2 tremors then 1 score was given, animals showed 3 or 5 tremors in 5 min then 2 score was given and for 6 or more tremors, score was given 3 . Akinesia was determined by holding the tail of animal and putting the front paws on the platform and let the animal to walk while holding (number of steps taken with forelimbs of animal was counted for $3 \mathrm{~min}$ ) and muscular rigidity was determined by suspending the animal with forelimbs on middle part of horizontal glass rod $(0.5 \mathrm{~cm}$ diameter $)$ at the height of $25 \mathrm{~cm}$ above the table top and time to fall on the bottom surface was measured. The cut-off was kept for $1 \mathrm{~min}$. The animals was treated with daidzein (50 \&100 mg/kg, p.o.), or L-dopa-carbidopa (30 mg/kg, p.o.) $60 \mathrm{~min}$ before administration of reserpine for 5 consecutive days (Colpaert, 1987; Vandana et al.; 2015).

\section{Locomotor activity}

After evaluation of tremors, akinesia, and muscular rigidity, locomotor activity was evaluated by using actophotometer. The apparatus consist of photoelectric cells, which are connected in circuit with a counter. When the beam of light falling on the photocell is cut off by the animal, a count was recorded for $10 \mathrm{~min}$ (Vandana et al., 2015).

\section{Rotarod activity}

The latency to grip strength was evaluated by using rota rod apparatus. Each animal was placed on rotating rod $(20 \mathrm{rpm})$ and latency to fall down was recorded in different groups of animals (Goel, Goel, Kumar, 2011).

\section{Biochemical estimations}

Dissection and homogenization: Animals were sacrificed by spinal dislocation immediately after behavioral assessments. The complete brain was removed and $10 \%(\mathrm{w} / \mathrm{v}-1)$ tissue homogenates were prepared

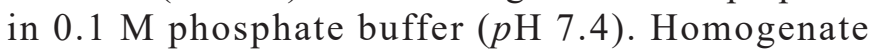
was centrifuged for 20 minutes at $15000 \mathrm{rpm}$ and the supernatant was used for estimation of lipid peroxidation and reduced glutathione levels.

Lipid peroxidation assay: The quantitative measurement of lipid peroxidation was perfomed according to the method of Ohkawa, Ohishi, Yagi, 1979. The amount of malondialdehyde (MDA) was measured by reaction with (TBA) thiobarbituric acid $535 \mathrm{~nm}$ using 
Shimadzu Spectrophotometer. The values were calculated using molar extinction coefficient of chromophore $\left(1.56 \times 10^{-6} \mathrm{~m} / \mathrm{cm} / 1\right)$ and expressed as $n$ moles formed per $\mathrm{mg}$ of protein in the tissue.

\section{Protein estimation}

The protein content was measured according to the method of Lowry, Rosebrough, Farr, 1951, using bovine serum albumin as standard. Protein reacts with the folin's ciocalteau phenol reagent to give colored complex. The color developed is due to reaction of alkaline copper with the protein and the reduction of phosphomolybdate by tyrosine and tryptophan present in the protein.

\section{Estimation of reduced glutathione}

Reduced glutathione was estimated according to the method described by Ellman (1959). Rats was sacrificed by instant decapitation. The brains was quickly removed and washed with ice cold saline. $2 \mathrm{~mL}$ of $10 \%$ homogenate, which was prepared in $\mathrm{KCl}$ solution, was taken and add 2.5 $\mathrm{mL}$ of $0.02 \mathrm{M}$ EDTA. Shake it vigorously. Take out $2 \mathrm{~mL}$ of the above mixture and add $4 \mathrm{~mL}$ of cold distilled water and $1 \mathrm{~mL}$ of $50 \%$ TCA and shake it for 10 minutes, later the content was transferred to centrifuged tube and centrifuged at $300 \mathrm{rpm}$ for $15 \mathrm{~min}$. Following centrifugation, $2 \mathrm{~mL}$ of the supernatant would be mixed with $4 \mathrm{~mL}$ of $0.4 \mathrm{M}$ tris buffer (PH 8.9). The whole solution was mixed well and $0.1 \mathrm{~mL}$ of $0.01 \mathrm{M}$ DTNB was added, the absorbance was read with in $5 \mathrm{~min}$ of addition of DTNB at $412 \mathrm{~nm}$ against reagent blank with no homogenate. For blank readings, instead of $2 \mathrm{~mL}$ of homogenate $2 \mathrm{~mL}$ of distilled water was added. Results were calculated and expressed as micro moles $(\mu \mathrm{mol})$ per gram of tissue weight.

Histological Examination: Samples of brain were stored in $10 \%$ formalin fixative solution, cut to 4- $\mu \mathrm{m}$ thickness and stained by the Hematoxylin and Eosin. Sections were observed under light microscope $(400 \times)$ for axonal degeneration and histopathological changes(Sudohet al.; 2004). Histopathological assessment was done at I.T.S Dental College Ghaziabad.

\section{Statistical analysis}

All the results are expressed as mean \pm standard error mean (SEM) followed by analysis of variance (ANOVA) along with Dunnett's ' $t$ ' test using SPSS software. The $\mathrm{p}<0.05$ was considered to be statistically significant.

\section{RESULTS}

\section{Effect of daidzein on Akinesia, tremor and muscular rigidity}

Treatment with reserpine for 5 days produces tremors, and akinesia in animals. The intensity of numbers of tremors, and akinesia were significantly decreased by daidzein $(50$ and $100 \mathrm{mg} / \mathrm{kg}$ ) carbidopa + levodopa $(30 \mathrm{mg} / \mathrm{kg})$ and combination of [(carbidopa + levodopa) and daidzein] significantly $(\mathrm{p}<0.01)$ as compared with control, reserpine and (carbidopa and levadopa) treated groups (Table II).

TABLE II - Effect of daidzein on muscular rigidity, tremors, akinesia in reserpine-induced motor defects

\begin{tabular}{lcccc}
\hline Group & Treatment & $\begin{array}{c}\text { Akinesia } \\
\text { (no. of steps taken } \\
\text { with forelimbs) }\end{array}$ & $\begin{array}{c}\text { Tremor } \\
\text { (score) }\end{array}$ & $\begin{array}{c}\text { Muscular rigidity } \\
\text { (duration of suspension } \\
\text { in seconds) }\end{array}$ \\
\hline 1 & Control (CMC in Saline) & $38 \pm 0.4$ & 0 & $35 \pm 0.3$ \\
2 & reserpine $(5 \mathrm{mg} / \mathrm{kg})$ & $18 \pm 0.57^{\mathrm{a}}$ & $4 \pm 0.33$ & $9 \pm 0.2^{\mathrm{a}}$ \\
3 & Control (DMSO) & $37 \pm 1.2^{\mathrm{a}, \mathrm{b}}$ & 0 & $12 \pm 0.2^{\mathrm{a}, \mathrm{b}}$ \\
4 & $\mathrm{~L}-$ dopa + carbidopa $(100 \mathrm{mg} / \mathrm{kg})$ & $23 \pm 0.86^{\mathrm{a}}$ & $1 \pm 0.22$ & $32 \pm 0.8^{\mathrm{a}}$ \\
5 & daidzein $(50 \mathrm{mg} / \mathrm{kg})$ & $25 \pm 0.80^{\mathrm{a}, \mathrm{b}, \mathrm{c}}$ & $2 \pm 0.33$ & $16 \pm 0.7^{\mathrm{a}, \mathrm{b}, \mathrm{c}}$ \\
6 & daidzein $(100 \mathrm{mg} / \mathrm{kg})$ & $28 \pm 0.7^{\mathrm{a}, \mathrm{b}, \mathrm{c}}$ & $2 \pm 0.21$ & $25 \pm 0.8^{\mathrm{a}, \mathrm{b}, \mathrm{c}}$ \\
7 & $\mathrm{~L}$-dopa + carbidopa + daidzein & $33 \pm 0.1^{\mathrm{a}, \mathrm{b}, \mathrm{c}}$ & $1 \pm 0.21$ & $28 \pm 0.6^{\mathrm{a}, \mathrm{b}, \mathrm{c}}$ \\
& $(100 \mathrm{mg} / \mathrm{kg}+50 \mathrm{mg} / \mathrm{kg})$ & & & $32 \pm 0.1^{\mathrm{a}, \mathrm{b}, \mathrm{c}}$ \\
\hline
\end{tabular}

All values were expressed as mean \pm S.E.M $(n=6),{ }^{a} \mathrm{p}<0.001$ when compared with control group, ${ }^{\mathrm{b}} \mathrm{P}<0.01$ when compared to reserpine and ${ }^{\mathrm{C}} \mathrm{P}<0.001$ when compared to carbidopa + levodopa ( $30 \mathrm{mg} / \mathrm{kg}$ ) (ANOVA followed by Dunnett's test). 


\section{Effect of drug on Actophotometer and Rotarod}

Treatment with reserpine for 5 days produces weak muscle strength in animals. Muscle strength significantly $(\mathrm{p}<0.01)$ increased by daidzein $(50 \mathrm{mg} / \mathrm{kg})$, daidzein (100 mg/kg). Carbidopa + levodopa (30 mg/kg), and combination of [carbidopa + levodopa and daidzein] and the locomotor activity is also increased significantly $(\mathrm{p}<0.01)$ with daidzein $(50 \mathrm{mg} / \mathrm{kg})$, daidzein $(100 \mathrm{mg} / \mathrm{kg})$. Carbidopa + levodopa (30 mg/kg), and combination of [carbidopa + levodopa and daidzein] when compared with the reserpine group (Table III).

\section{Biochemical estimation}

The lipid peroxidation levels and reduced glutathione levels significantly decreased and increased respectively with daidzein $(50 \mathrm{mg} / \mathrm{kg})$, daidzein $(100 \mathrm{mg} / \mathrm{kg})$. Carbidopa + levodopa (30 mg/kg), and combination of [carbidopa + levodopa and daidzein] as compared to reserpine and control group (Table IV)

\section{Detection of neuronal death in sections stained with hematoxylin and eosin}

Hematoxylin and eosin staining was used to estimate cell degeneration. Neuronal cells stained with H\&E were quantified in the surface of the substantia nigra. Each midbrain section was viewed at low power $(\times 10$ magnification) and the outlines of SNpc were determined. Histological assessment demonstrated that control groups rats showed normal SNpc neuronswhereas reserpine treated rats showed marked neuronal degeneration. The mean number of SNpc neurons was higher in control

TABLE III - Effect of daidzein on locomotor activity, and grip strength in reserpine-induced motor defects

\begin{tabular}{lccc}
\hline Group & Treatment & $\begin{array}{c}\text { Locomotor activity } \\
\text { (in 10 minutes) }\end{array}$ & $\begin{array}{c}\text { Grip strength } \\
\text { (latency to fall in seconds) }\end{array}$ \\
\hline 1 & Control (CMC in Saline) & $77.3 \pm 1.8$ & $31.5 \pm 1.08$ \\
2 & reserpine $(5 \mathrm{mg} / \mathrm{kg})$ & $43.8 \pm 4.1$ & $17.3 \pm 0.71$ \\
3 & Control $(\mathrm{DMSO})$ & $66.3 \pm 1.3$ & $24.1 \pm 0.98^{\mathrm{a}, \mathrm{b}}$ \\
4 & $\mathrm{~L}-$ dopa + carbidopa $(100 \mathrm{mg} / \mathrm{kg})$ & $49.6 \pm 2.1^{\mathrm{a}, \mathrm{b}}$ & $19.8 \pm 1.8^{\mathrm{a}, \mathrm{b}}$ \\
5 & daidzein $(50 \mathrm{mg} / \mathrm{kg})$ & $54.5 \pm 3.16^{\mathrm{a}, \mathrm{c}}$ & $21.1 \pm 1.92^{\mathrm{b}}$ \\
6 & daidzein $(100 \mathrm{mg} / \mathrm{kg})$ & $61.2 \pm 2.54^{\mathrm{b}, \mathrm{c}}$ & $23.1 \pm 1.88^{\mathrm{a}, \mathrm{b}, \mathrm{c}}$ \\
7 & L-dopa + carbidopa + daidzein & $65.5 \pm 3.28^{\mathrm{a}, \mathrm{b}}$ & $27.3 \pm 1.17^{\mathrm{b}, \mathrm{c}}$ \\
& $(100 \mathrm{mg} / \mathrm{kg}+50 \mathrm{mg} / \mathrm{kg})$ & & \\
8 & L-dopa + carbidopa + daidzein & $70.3 \pm 2.39^{\mathrm{a}, \mathrm{b}, \mathrm{c}}$ & $29.6 \pm 1.07^{\mathrm{a}, \mathrm{b}, \mathrm{c}}$ \\
\hline
\end{tabular}

All values were expressed as mean \pm S.E.M. $(\mathrm{n}=6),{ }^{\mathrm{a}} \mathrm{P}<0.001$ when compared with control group ${ }^{\mathrm{b}} \mathrm{P}<0.01$ when compared to reserpine ${ }^{\mathrm{c}} \mathrm{P}<0.001$ when compared to carbidopa + levodopa $30 \mathrm{mg} / \mathrm{kg}$ (ANOVA followed by Dunnett's 't' test).

TABLE IV - Effect of daidzein on biochemical parameters in brain tissue

\begin{tabular}{lccc}
\hline Group & Treatment & $\begin{array}{c}\text { TBARS } \\
\text { n mol (MDA/ mgProtein) }\end{array}$ & $\begin{array}{c}\text { GSH } \\
(\boldsymbol{\mu m o l s} / \text { gm of tissue weight) }\end{array}$ \\
\hline 1 & Control $(\mathrm{CMC}$ in Saline) & $0.78 \pm 0.03$ & $0.001 \pm 6.73$ \\
2 & reserpine $(5 \mathrm{mg} / \mathrm{kg})$ & $0.87 \pm 0.05$ & $0.001 \pm 2.0$ \\
3 & Control $(\mathrm{DMSO})$ & $0.64 \pm 0.02^{\mathrm{a}}$ & $0.001 \pm 5.0^{\mathrm{a}}$ \\
4 & L-dopa + carbidopa $(100 \mathrm{mg} / \mathrm{kg})$ & $0.58 \pm 0.02^{\mathrm{a}, \mathrm{b}}$ & $0.0016 \pm 4.7^{\mathrm{a}}$ \\
5 & daidzein $(50 \mathrm{mg} / \mathrm{kg})$ & $0.48 \pm 0.01^{\mathrm{a}, \mathrm{b}, \mathrm{c}}$ & $0.0017 \pm 4.9^{\mathrm{a}, \mathrm{b}}$ \\
6 & daidzein $(100 \mathrm{mg} / \mathrm{kg})$ & $0.46 \pm 0.06^{\mathrm{a}, \mathrm{b}, \mathrm{c}}$ & $0.0017 \pm 5.4^{\mathrm{a}, \mathrm{b}, \mathrm{c}}$ \\
7 & L-dopa + carbidopa + daidzein & $0.44 \pm 0.02^{\mathrm{a}, \mathrm{b}, \mathrm{c}}$ & $0.0018 \pm 5.08^{\mathrm{a}, \mathrm{b}, \mathrm{c}}$ \\
& $(100 \mathrm{mg} / \mathrm{kg}+50 \mathrm{mg} / \mathrm{kg})$ & & \\
8 & L-dopa + carbidopa + daidzein & $0.41 \pm 0.02^{\mathrm{a}, \mathrm{b}, \mathrm{c}}$ & $0.0018 \pm 5.80^{\mathrm{a}, \mathrm{b}, \mathrm{c}}$ \\
\hline
\end{tabular}

All values were expressed as mean \pm S.E.M. $(\mathrm{n}=6),{ }^{\mathrm{a}} \mathrm{p}<0.01$ when compared with control group; ${ }^{\mathrm{b}} \mathrm{p}<0.01$ when compared to reserpine; ${ }^{\mathrm{c}} \mathrm{P}<0.01$ when compared to carbidopa + levodopa ( $30 \mathrm{mg} / \mathrm{kg}$ ) (ANOVA followed by Dunnett's test). 
group in comparison to reserpine group. Pharmacological treatment with daidzein $(50 \mathrm{~m} / \mathrm{kg} \& 100 \mathrm{mg} / \mathrm{kg})$, carbidopa + levodopa $(30 \mathrm{mg} / \mathrm{kg}$ ) alone or combined therapy showed higher percentage increases in number of SNpc dopaminergic neurons and less neuronal degeneration as compared to reserpine group (Figure1).

\section{DISCUSSION}

Parkinson Disease is a disorder of the central nervous system, involving primarily a degeneration of certain nerve cells in deep parts of the brain called the basal ganglia, and in particular a loss of nerve cells (or neurons) in a part of the brainstem called the substantia nigra (Reeve, Simcox, Turnbull, 2014). These cells make the neurochemical messenger dopamine, which is partly responsible for starting a circuit of messages that coordinate normal movement (Hélie, Paul, Ashby, 2012). Normally used antiparkinson drug for decreasing Parkinson activity such as carbidopa + levodopa. Therefore, this study conducted to evaluate and the effect of daidzein in Parkinson and to wide knowledge of mechanism involved in Parkinson disease. In
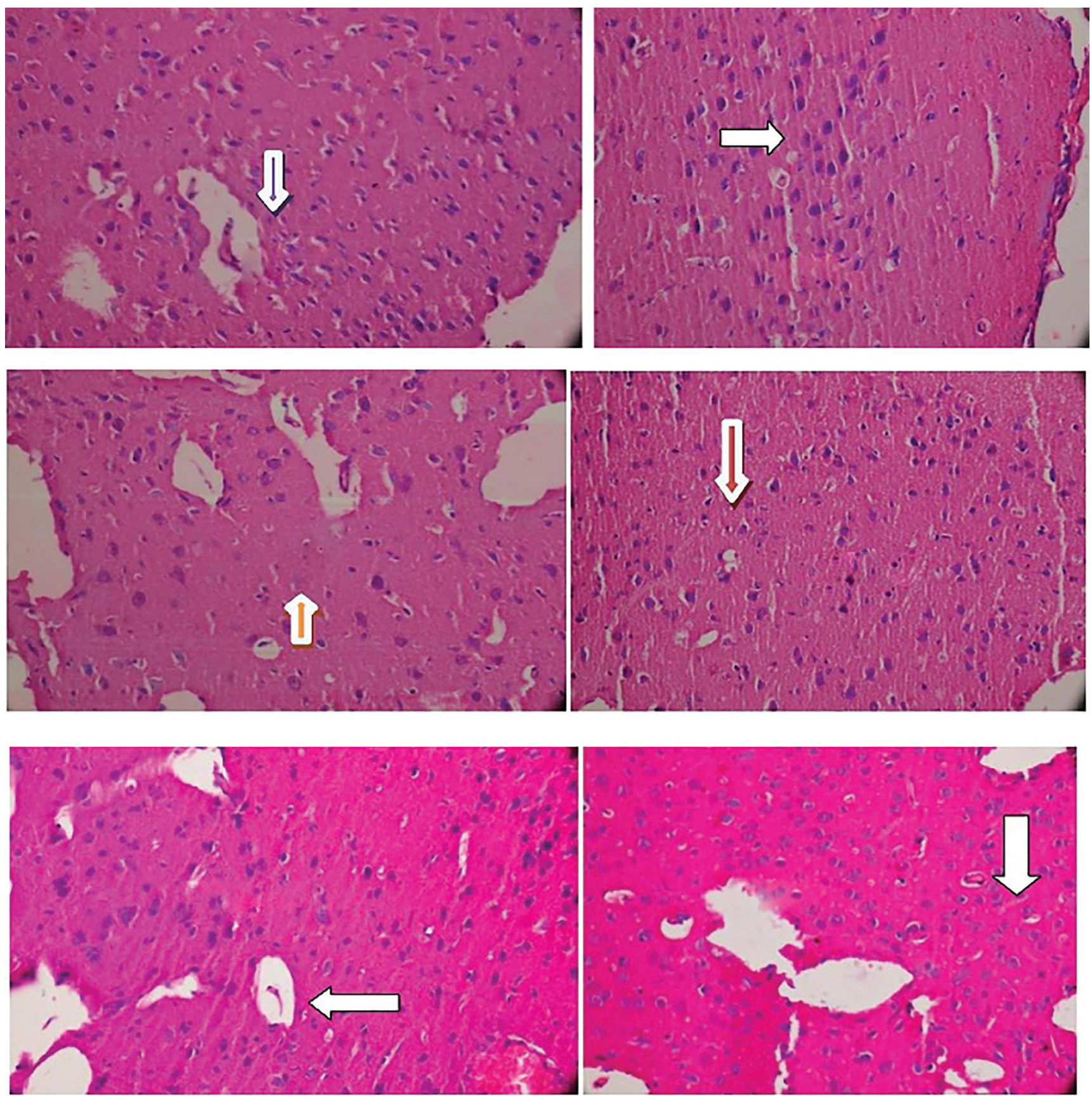

FIGURE 1 - Histopathological evaluation of normal, reserpine and drug treated groups. 
this study, reserpine model are used to induce Parkinson in wistar rats. Reserpine induces muscular rigidity, tremors, and akinesia by depletion of central catecholamine storage (Vandana et al.; 2015). Daidzein (50 and $100 \mathrm{mg} / \mathrm{kg}$, p.o.) and the combination of L-dopa and carbidopa with daidzein produced a significant reduction in these symptoms in rats.

Daidzein was also able to increase the locomotor activity and grip strength in rats. Reserpine induced motor defect was significantly reversed by daidzein. Amelioration of symptoms of reserpine by daidzein demonstrates anti-parkinsons activity.

Oxidative stress is one of the major reasons for nerve damage in many neurodegenerative disorders (Mosley et al.; 2006). In Parkinson's disease, oxidation of dopamine by monoamine oxidase- $\mathrm{B}$, and aldehyde dehydrogenase generates hydroxyl free radicals in the presence of ferrous ions (basal ganglia are rich in iron) (Subramaniam, Chesslet, 2013). The study showed that $\mathrm{N}$-acetyl cysteine, an antioxidant has direct effect on the dopamine system of Parkinson patients (Monti et al.; 2016). Hence, to find out oxidative stress at various levels the defensive antioxidant enzymes in rat brain were measured. LPO is the measure of the excessive oxidation of the lipids in the body indicating increased superoxide production. Therefore, the oxidative stress indices were estimated in rat brain such as LPO and reduced GSH (Verma, Nehru, 2009). The neuroprotective activity of the daidzein may be due to its antioxidant property, which reinforces antiparkinson activity of daidzein. In histopathological study substantia nigra showed neuronal degeneration (Carbidopa + Levodopa30 mg/kg $+50 \mathrm{mg} / \mathrm{kg}$ daidzein + $5 \mathrm{mg} / \mathrm{kg}$ reserpine $) \&(100 \mathrm{mg} / \mathrm{kg}$ daidzein $+30 \mathrm{mg} / \mathrm{kg}$ carbidopa + levodopa $+5 \mathrm{mg} / \mathrm{kg}$ reserpine) showed better result with no swelling, it was show significant effect. The study showed that quercetin can reduce the neuronal death due to its antioxidant effect (El-Horany et al.; 2016).

So, the above behavioral and biochemical results suggest that daidzein has the ability to improve symptoms of Parkinsonism, in part, by the restoring the level of dopamine, and by the regulation of the antioxidant system. Thus, antioxidant and neuroprotective activities may be responsible for antiparkinsons effect. Hence, daidzein may be useful as a neuroprotective agent in the treatment of PD.

\section{CONCLUSION}

Parkinson disease is a chronic, progressive, neurodegenerative disorder with multiple pharmacological treatments. The drugs employed clinically in treatment and management of Parkinson was associated with multiple other adverse effect which additionally make its treatment more difficult thus this research was aimed at examining daidzein in Parkinson and open new vistas in treatment and management of this disease.So, the results indicated the protective effect of daidzein against Parkinson disease induced by reserpine model test of wistar rats. The drug can therefore offer an alternative approach in parkinson state. Conclusively additional investigation is required on other animal models to obtain a dependable oversight of the outcome of daidzein on Parkinson in actual clinical scenario.

\section{ACKNOWLEDGEMENT}

We thank ITS College of Pharmacy and I.T.S Dental College for their assistance to complete this project.

\section{REFERENCES}

Bayer T, Colnot T, Dekant W. Disposition and biotransformation of the estrogenic isoflavonedaidzein in rats. Toxicol Sci. 2001;62(2):205-211.

Colpaert FC. Pharmacological characteristics of tremor, rigidity and hypokinesia induced by reserpine in rat. Neuropharmacology. 1987;26(9):1431-1440.

Ellman GH. Tissue sulfhydryl groups. Arch Biochem Biophys. 1959;82(1):70-77.

Fonseca D, Wendy WE.Daidzein together with high calcium preserve bone mass and biomechanical strength at multiple sites in ovariectomized mice.Bone.2004;35(2): 489-497.

Goel R, Goel A, Kumar Y. Influence of carvedilol on anticonvulsant effect of gabapentin. Acta Neurol Belg. 2011;111(4):296-305.

Gołembiowska K, Dziubina A. Kowalska M, Kamiñska K. Paradoxical effects of adenosine receptor ligands on hydroxyl radical generation by L-DOPA in the rat striatum. Pharmacol Reports. 2007;60(3):319-330.

Hélie S, Paul EJ, Ashby FG. Simulating the effects of dopamine imbalance on cognition: From positive affect to Parkinson's disease.Neural Netw. 2012;32:74-85.

E1-HoranyHE, El-latifRNA,ElBatshMM,EmamMN. Ameliorative effect of quercetin on neurochemical and behavioral deficits in rotenone rat model of parkinson's disease: modulating autophagy (quercetin on experimental parkinson's disease). J Biochem Mol Toxicol. 2016;30(7):360-369. 
Jenner P, Dexter T, Sian J, Schapira H, Marsden CD.Oxidative stress as a cause of nigral cell death in Parkinson's disease and incidental Lewy body disease. Ann Neurol. 1992;32(Suppl): S82-7.

Lorraine VK, Anthony EL. Parkinson's disease.Lancet. 2015;386(9996):896-912.

Lowry OH, Rosebrough NJ, Farr AL. Protein measurement with the folin phenol reagent. J Biol Chem. 1951;193(1):265-275.

Monti DA, Zabrecky G, Kremens D, Liang TW, Wintering NA, Cai J, Wei X.N-Acetyl cysteine may support dopamine neurons in parkinson's disease: preliminary clinical and cell line data. PLoS One. 2016;11(6):1-15.

Mosley RL, Benner EJ, Kadiu I, Thomas M, Boska MD, Hasan K, Laurie C, Gendelman HE. Neuroinflammation, oxidative stress, and the pathogenesis of Parkinson's disease. ClinNeurosciRes. 2006;6(5):261-281.

Ohkawa H, Ohishi N, Yagi K. Assay of lipid peroxides in animal tissues by thiobarbituric acid reaction. Anal Biochem. 1979;95(2):351-358.

Pavan P, Venkatraman S. Literaute review on history and screening models for parkinsonism.Int J Pharmacol Screening Method. 2012;2:24-37.

Reeve A, Simcox E, Turnbull D. Ageing and Parkinson's disease: Why is advancing age the biggest risk factor? Ageing Res Reviews. 2014;14:19-30.
Ricciotti HA, Khaodhiar L,Blackburn GL. Daidzein-rich isoflavone-aglycones for menopausal symptoms. Int J Gyne Obs. 2005;89 (1):65-66.

Subramaniam SR, Chesselet MF.Mitochondrial dysfunction and oxidative stress in Parkinson's disease.Progress Neurobiol. 2013;106:17-32.

Sudoh Y, Desai SP, Haderer AE, Sudoh S, Gerner P, Anthony DC, et al. Neurologic and histopathologic evaluation after high volume intrathecal amitriptyline. RegAnesth Pain Med. 2004;29(5):434-440.

Vandana SN, Laxman AK, Shankar SZ, Amit BK. Neuroprotective potential of Beta vulgaris L. in Parkinson's disease. Ind J Pharmacol. 2015;47(4):403-408.

Verma R, Nehru B. Effect of centrophenoxine against rotenoneinduced oxidative stress in an animal model of Parkinson's disease.Neurochem Int. 2009;55(6):369-375.

Xiaoping L, Naomi SuzukiYR, Laxmi S, Yoshinori O, Shinya $\mathrm{S}$. Anti-breast cancer potential of daidzein in rodents.Life Sci. 2012;91(11-12):415-419.

Received for publication on 23 ${ }^{\text {rd }}$ May 2018 Accepted for publication on $24^{\text {th }}$ September 2018 